\title{
Geodynamic Implications of the Latest Chattian-Langhian Central-Western Peri-Mediterranean Volcano- Sedimentary Event: A Review
}

\author{
Manuel Martín-Martín, ${ }^{1, \star}$ Francesco Guerrera, ${ }^{2}$ and Mario Tramontana ${ }^{3}$ \\ 1. Departamento de Ciencias de la Tierra y del Medio Ambiente, Universidad de Alicante, Campus San Vicente, \\ San Vicente del Respeig, AP 99, 03080 Alicante, Spain; 2. Ex-Dipartimento di Scienze della Terra, \\ della Vita e dell'Ambiente, Università degli Studi di Urbino Carlo Bo, Campus Scientifico \\ Enrico Mattei', 61029 Urbino, Italy; 3. Dipartimento di Scienze Pure e Applicate, \\ Università degli Studi di Urbino Carlo Bo, Campus \\ Scientifico E. Mattei, 61029 Urbino, Italy
}

\begin{abstract}
A B S T R A C T
High amounts of Chattian-Langhian orogenic magmatism have generated volcaniclastic deposits that are interbedded within the penecontemporaneous sedimentary marine successions in several central-western peri-Mediterranean chains. These deposits are widespread in at least 41 units of different basins located in different geotectonic provinces: (1) the Africa-Adria continental margins (external units), (2) the basinal units resting on oceanic or thinned continental crust of the different branches of the western Tethys, (3) the European Margin (external units), and (4) the Western Sardinia zone (Sardinia Trough units). The emplacement of volcaniclastic material in marine basins was controlled by gravity flows (mainly turbidites; epiclastites) and fallout (pyroclastites). A third type comprises volcaniclastic grains mixed with marine deposits (mixed pyroclastic-epiclastic). Calc-alkaline magmatic activity is characterized by a medium- to high-potassium andesite-dacite-rhyolite suite and is linked to complex geodynamic processes that affected the central-western Mediterranean area in the 26 to $15 \mathrm{My}$ range. The space/time distribution of volcaniclastites, together with a paleogeographic reconstructions, provide keys and constraints for a better reconstruction of some geodynamic events. Previous models of the central-western Mediterranean area were examined to compare their compatibility with main paleotectonic and paleogeographic constraints presented by the main results of the study. Despite the complexity of the topic, a preliminary evolutionary model based on the distribution of volcaniclastites and active volcanic systems is proposed.
\end{abstract}

Online enhancements: appendix tables

\section{Introduction}

The stratigraphic record, timing of deformation, and geodynamic evolution of the central-western Mediterranean orogens are still debated because the interpretation of their geological history is linked to both the reconstruction of the initial paleogeography and the closure of the different branches of the Tethys oceanic basin (e.g., Durand Delga 1980; Frizon de Lamotte et al. 2000; Guerrera et al. 2005; Handy

Manuscript received June 26, 2018; accepted March 9, 2019; electronically published December 5, 2019.

* Author for correspondence; email: manuel.martin.m3@gmail .com. et al. 2010; Carminati and Doglioni 2012; Guerrera and Martín-Martín 2014; van Hinsbergen et al. 2015; Critelli et al. 2017).

The presence of volcaniclastic deposits, interbedded within the uppermost Chattian-Langhian marine sedimentary units of some chains (the Apennines, the Maghrebids, the Betic Cordillera, etc.), has been known for a long time (e.g., Clari et al. 1988; Critelli and Monaco 1993; Bonci et al. 1994; Ruffini et al. 1995; D'Atri et al. 2001; de Capoa et al. 2002; Guerrera et al. 2015; Giordano et al. 2017). The study of these deposits provides important constraints for the reconstruction of the paleogeography 
and orogenic evolution of the central-western Mediterranean region.

Volcaniclastic products have been generated by a consistent penecontemporaneous orogenic calcalkaline magmatism, which has been recognized in some sectors of the Mediterranean area (e.g., Duggen et al. 2005; Allagna et al. 2010; Carminati et al. 2010, 2012; Lustrino et al. 2011, 2013; Savelli 2015). The emplacement of volcaniclastic materials transported into the depositional marine areas is due to two main mechanisms: reworking processes and volcanic fallout.

Current knowledge does not allow direct correlations between specific volcanoes or related activity and secondary products, mainly because the primary volcanic products are usually missing. Interdisciplinary studies, integrated with literature data, have been carried out on the secondary products (stratigraphy, age, field lithofacies, grain size, emplacement processes, and sedimentary structures and microscopic analytical determination of petrofacies), allowing characterization of the volcanosedimentary successions, which is a prerequisite for recognition and location of volcanic source areas. Unfavorably, minero-petrographic studies are scarce; especially lacking are the geochemical studies concerning the volcaniclastic deposits studied, thus precluding reliable areal and lateral correlations over long distances. For these reasons, it is clear that a study of volcaniclastites could provide some important indications for paleogeographic and paleotectonic reconstructions, although interpretations at a regional scale still prove difficult given the limited coverage of the literature.

Taking into account that volcanic ash, depending on the grain size, can be transported over long distances and that the reworking processes of volcanic material constitute important keys for the locating of volcanic source areas, two main problems have been approached in this paper: Can the areal distribution, characterization, and correlation of volcaniclastites be used as indicators in reconstructing the space-time relationships between these products and the location of the volcanic activity? And could the paleogeography and geodynamic evolution of the central-western Mediterranean region be better defined?

This study presents new data plus a review of available literature on the peri-Mediterranean chains. The study (1) shows the distribution and main features of the uppermost Chattian-Langhian volcaniclastites deposited along the Apennine-MaghrebianBetic Chains; (2) shows the distribution of the penecontemporaneous volcanites, which are paleogeographically and paleotectonically contextualized; and (3) proposes an evolutionary model for the central-western Mediterranean area.

\section{Geological Framework}

The central-western Mediterranean region is bordered by the Alpine Chains (developed during a riftingdrifting-oceanization Mesozoic phase, followed by convergence, subduction, and collision during Cenozoic times). According to the ages of the subduction, collisions, and deformation, the Alpine evolution can be divided into Eo-Alpine, mainly during the Cretaceous to Paleogene, and Neo-Alpine, mainly during the Neogene. The Iberian Range, the Pyrenees, the north of Corsica, the Alps, and some units of the northern Apennines have mainly experienced an EoAlpine evolution (Martín-Martín et al. 2001). The Betics, the Maghrebides (Rif, Tell, Sicily, and southern Calabria), and the Apennines are related to the Neo-Alpine phase and thus are affected by OligoMiocene volcano-sedimentary events, the main focus of this paper (fig. 1). According to previous studies (Guerrera et al. 1993, 2005; Guerrera and MartínMartín 2014) the Cenozoic successions involved in the Neo-Alpine chains were deposited in three major paleogeographic elements on which many authors agree: (1) the internal domains of the Betic, Rif, Tell, and Calabria-Peloritani Arc Chains with a preAlpine continental basement (Paleozoic or older crystalline rocks previously affected by the Variscan orogeny) with carbonate Mesozoic-Cenozoic covers strongly deformed into nappes and frequently affected by Alpine metamorphism (Martín-Algarra 1987); (2) the Maghrebian Flysch Basin Domain, stretching from the Betic Cordillera up to the southern Apennines Lucanian Basin (oceanic and/or transitional crust); and (3) the external domains, belonging to the Iberia and Africa-Adria Margins and made of a pre-Alpine continental crust, were followed by sedimentary carbonate Mesozoic-Cenozoic covers also deformed into nappes.

The origin of the internal domain units of the Betic Cordillera, Rif, and Tell (Maghrebian Chain) and the Calabria-Peloritani Arc is related to convergence and collision, mainly during Oligo-Miocene times, of an intermediate terrane or microplate (mesoMediterranean microplate sensu Guerrera and MartínMartín 2014 or Alboran-Kabylides-Peloritani-Calabria [AlKaPeCa] sensu Michard et al. 2002) against the respective margins (south Iberian and north African margins) of the Iberia and Africa-Adria plates. Since the Jurassic-Cretaceous, this terrane or microplate was located between the African and European plates surrounded by oceanic branches of the 


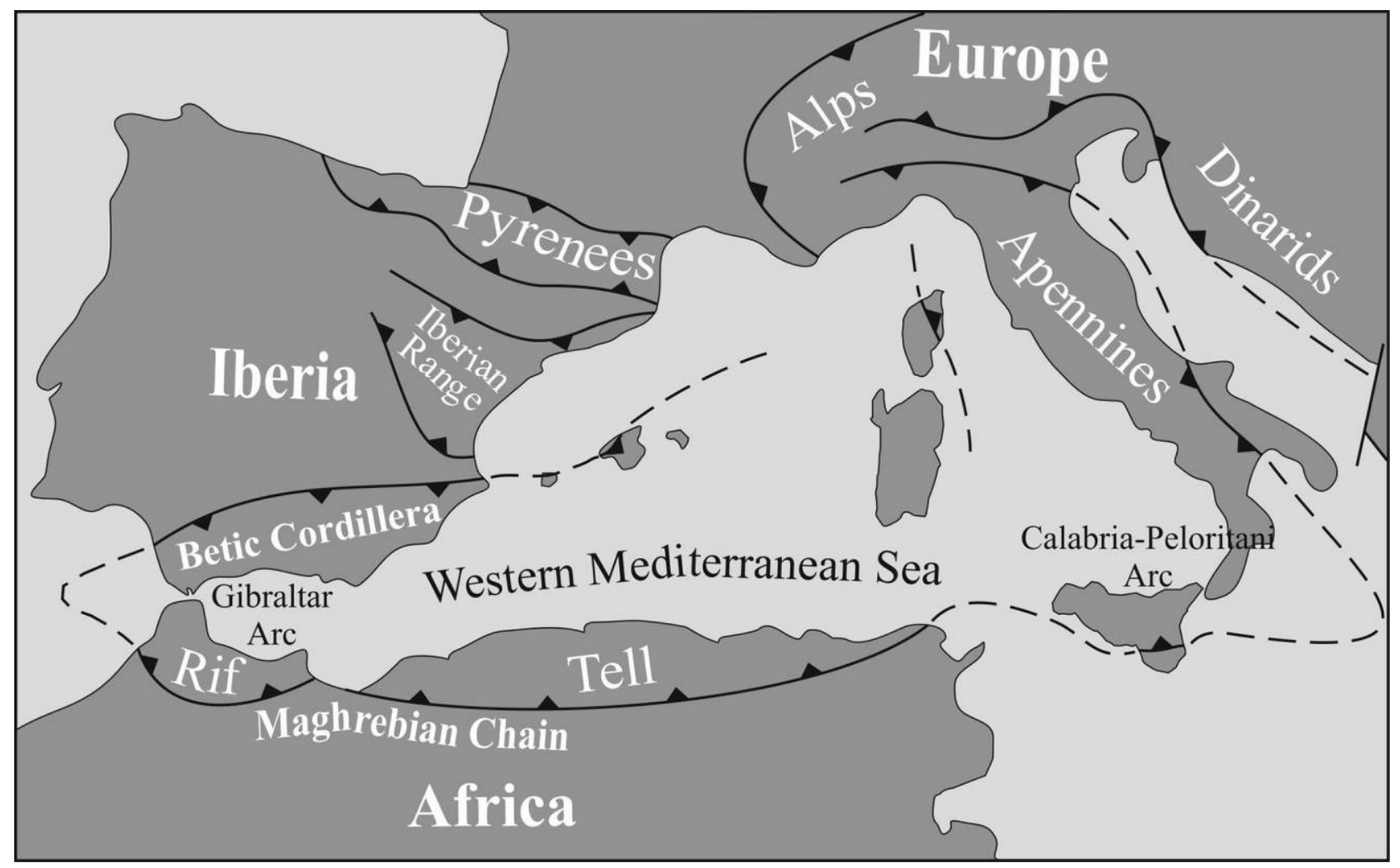

Figure 1. Simplified tectonic map of the peri-Mediterranean chains showing the Betic-Maghrebian-Apennine system, in which volcaniclastites interbedded within different sedimentary units are recognizable and coeval volcanic remnants are present. A color version of this figure is available online.

western Tethys (Martín-Algarra 1987; Doglioni 1992; Michard et al. 2002; Perri et al. 2013; Guerrera and Martín-Martín 2014; Critelli et al. 2017; Puga et al. 2017).

The resulting units from the Maghrebian Basin, located southward of the intermediate terrane or microplate, and its extension in the southern Apennines, and the Betic Cordillera are characterized by Cretaceous-Miocene thick clayey terrigenous successions deposited on deep oceanic/transitional crust that formed during the Jurassic and Early Cretaceous. These successions were deformed into nappes and tectonic mélanges during the early to middle Miocene due to the convergence and subduction of the Maghrebian Basin beneath the intermediate terrane (e.g., Durand Delga 1980; Durand Delga and Fontboté 1980; Wildi 1983; de Capoa et al. 2004; Guerrera and Martín-Martín 2014).

The units of the external domains are represented by nappes of different Mesozoic-Cenozoic successions deposited on the continental margins of the Iberian, Africa, and Adria plates. During the Miocene, with the new conditions of convergence and precollision, the formerly passive margins evolved into foreland basins (because of the flexure of basement in relation to the loading of the orogenic wedge of the internal units) characterized by prevalence of pelagic-hemipelagic sedimentary rocks or shallow marine sedimentation. The development of the BeticMaghrebian-Apennine nappes was diachronous (Guerrera and Martín-Martín 2014 and references therein). Indeed, the ages are synchronous and older in the Betic (Oligocene to early Miocene) and north Africa branches and become progressively younger from Sicily (Langhian) to the southern Apennines (Serravallian).

\section{Volcaniclastic Deposits}

In general, volcaniclastites can be derived from erosion of old volcanites (dating before the time of sedimentation) and pyroclasts-epiclasts (related to active volcanism penecontemporaneous with sedimentation). Only the latter have been considered in this article. When studying the pyroclasts-epiclasts, two main emplacement processes can be recognized. First, pyroclasic, epiclastic, and tuffites (sensu 
Schmid 1981 and Le Maître 2002) fallout generate volcaniclastites with several grain sizes: ashes, cinders, lapilli, etc. In distal areas, the normal hemipelagic sedimentation is sometimes interrupted by ash fallout deposits coming from the most explosive volcanic activity or by redeposition of ashes due to extremely diluted turbidites. Second, gravity flows (turbidites, slumping, etc.) generate volcanic epiclastites (volcanogenic material resulting from erosion and reworking of all type of volcanites in adjacent basins that are difficult to place).

These two emplacement processes have different paleogeographic implications. Reworked gravityflow deposits imply the absence of morphological barriers between volcanic sources and sedimentary basins, whereas the volcanic ash involved in the fallout processes can be transported over longer or shorter distances, which can be evaluated both according to the deposit thickness and grain size. The frequent occurrence of mixing of volcanoclastic materials and marine sediments generates different lithofacies that must be evaluated, case by case.

Volcaniclastic deposits show petrofacies consisting of different lithotypes, listed as "petrofacies" and "subpetrofacies" (sensu Schmid 1981 and Le Maître 2002). These deposits in the current study are always interbedded within marine successions. Volcaniclastites were classified into the following main types: pyroclastic deposits, mixed pyroclastic-epiclastic deposits, and epiclastic deposits mixed with marine deposits.

Pyroclastic deposits (volcanic clast content less than $90 \%$ ) are characterized by a gradual decrease in thickness and grain size of beds (from agglomerate to fine tuff) away from the possible source. Three subpetrofacies have been included in this typology: $1 \mathrm{~A}$, vitroclastic/crystal-vitroclastic tuffs; $1 \mathrm{~B}$, nonvitroclastic tuffs with bentonitites; and $1 \mathrm{C}$, nonvitroclastic ocraceous and blackish tuffs.

Mixed pyroclastic-epiclastic deposits (volcanic clast content of $25 \%-75 \%$ ) characterized by the appearance of the volcaniclastic material in turbiditic deposits (redeposition of eroded volcanic materials). In this typology four subpetrofacies have been included according to the sedimentary structures of the turbidites (Bouma 1962) and the volcaniclastic content: $2 \mathrm{~A}$, high-density turbidites with volcaniclastic content; 2B, low-density turbidites with volcaniclastic content; 2C, low-density turbidites with crystal-rich volcaniclastic content; and $2 \mathrm{D}$, lowdensity turbidites with glauconite and volcaniclastic content.

Epiclastic deposits mixed with marine deposits (volcanic clast content of $5 \%-25 \%$ ) consisting of nonvolcanic marine sediments (terrigenous, chemical precipitates or organogenic components), quartz or mica and a mixture of carbonates, siliceous rocks (cherts and siliceous marls) with fragments, or organic remains such as radiolaria and variable contents of fragments of volcanic ash.

The main features of the mentioned volcaniclastic deposits are synthesized in table A1 (tables A1-A4 are available online) with references to the original papers from the literature (Giammetti et al. 1968; Giannello and Gottardi 1969; Boulin et al. 1973; Chauve et al. 1973; Pieri and Rapisardi 1973; Hoyez and Andreieff 1975; Rivière and Courtois 1975; Bellon 1976; Rivière et al. 1977; Chiocchini et al. 1978; González Donoso et al. 1982; Borsetti et al. 1984; Perrone 1987; Clari et al. 1988; Rivière 1988; Carmisciano et al. 1989; Russo and Senatore 1989; Critelli and Le Pera 1990; Feinberg et al. 1990; Grandesso and Stefani 1990; Critelli 1991; Balogh et al. 1992, 1993; Faugères et al. 1992; Guerrera et al. 1992, 2004; Patacca et al. 1992; Puglisi and Carmisciano 1992; Santo and Senatore 1992; Soria et al. 1992, 1993; Critelli and Monaco 1993; Papini and Vannucci 1993; Tateo 1993; Bonci et al. 1994; D'Atri and Tateo 1994; Delle Rose et al. 1994a, 1994b; Soria 1994, 1998; Maaté et al. 1995; Ruffini et al. 1995; D'Atri et al. 1999, 2001; Cornamusini 2002; de Capoa et al. 2002, 2003; Di Staso and Giardino 2002; Zaghloul et al. 2002, 2007; Bonardi et al. 2003, 2005; Delfrati et al. 2003; Cammarosano et al. 2004; Poli et al. 2007; Hlila et al. 2008; Pescatore et al. 2012; Guerrera et al. 2015). Their areal distribution is shown in figure 2 . The units containing volcaniclastites, mentioned in the literature, in the periMediterranean chains have been listed according to their sedimentary basins in reference to the respective geotectonic provinces.

The frequency of the litho- and petrofacies, related to the different emplacement processes, results in all considered basins as follows: 32 units contain mixed deposits, 30 units show volcanic epiclastites, and 18 contain pyroclastites. This means that lithofacies 2 and 3 prevail on pyroclastites (lithofacies 1) even though the three types are often variably associated in the different successions (table A1). In addition, siliceous deposits (cherts and siliceous marls) are common in almost all units. A relationship seems to exist between volcanic activity and the "bloom" of siliceous organisms due to a major presence of silica in the ocean. These deposits are represented by the following lithofacies: siliceous marls, chert beds and/ or nodules, deposits very rich in radiolarian (silexites), spongolites, and so forth.

In summary, the analyzed volcaniclastites show great variability regarding the lithofacies, vertical and lateral distribution, the amount of volcaniclastic 


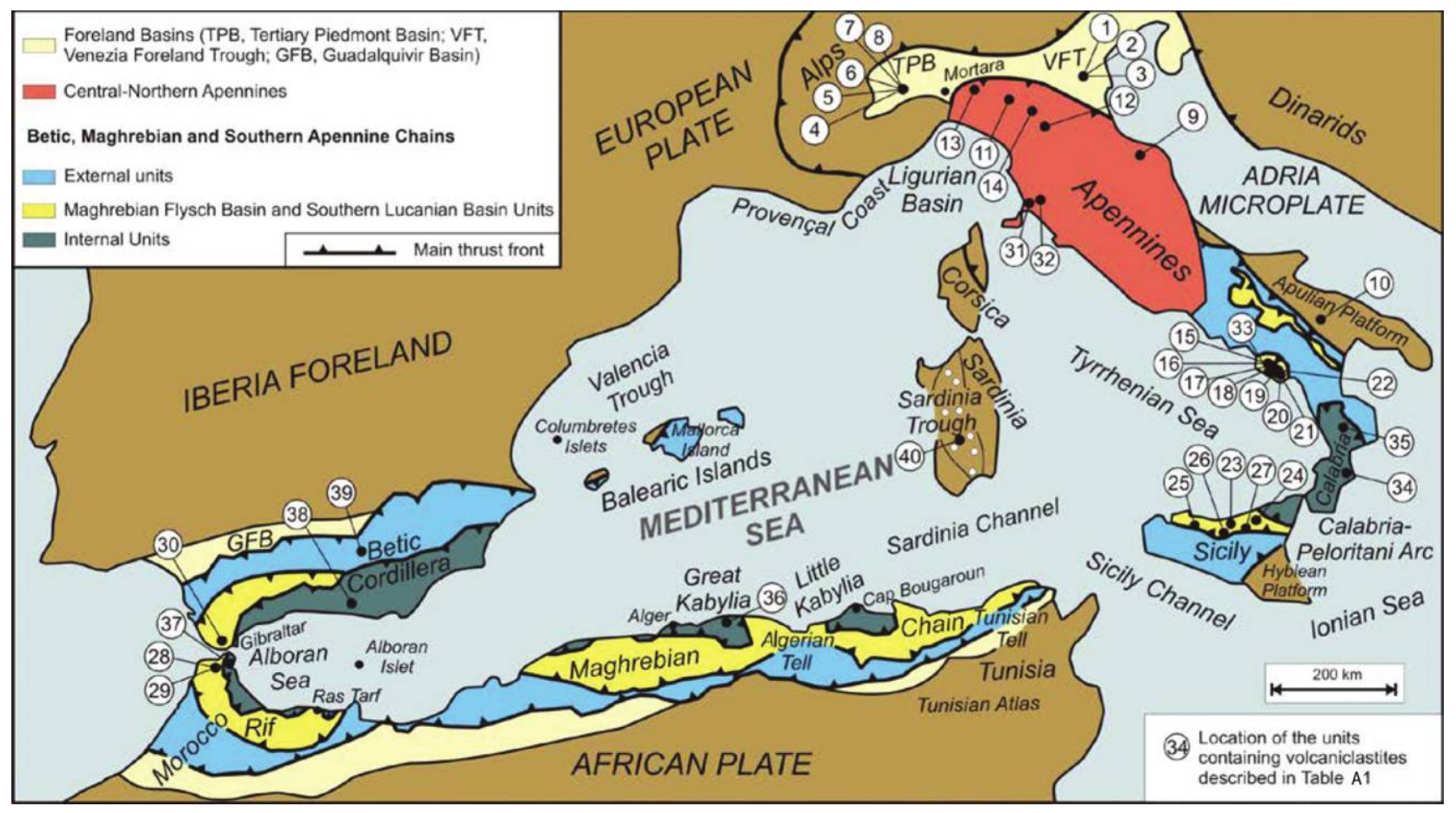

Figure 2. Distribution of the uppermost Chattian-Langhian volcano-sedimentary units along the Betic, Maghrebian, and Apennines orogens.

material, thickness, color, sedimentary structures, minero-petrographic features, and paleogeographic location of the basin.

\section{Volcanites}

Calc-alkaline magmatism (sensu Best 2003; according to the International Union of Geological Sciences) is mainly represented by medium- to highpotassium andesite-dacite-rhyolite suites that are typical products resulting from convergent plate margins and subduction. In the central-western Mediterranean area the Oligo-Miocene, calc-alkaline orogenic magmatism constitutes a signature recording the geodynamic activity along the involved continental margins (Carminati et al. 2012 and references therein) and plate boundaries. In fact, major calcalkaline volcanic activity (fig. 3), derived mainly from the convergent plate-margin tectonics, affected the Mediterranean Neo-Alpine chains during the latest Chattian-Langhian ( 26 to $15 \mathrm{My}$ ). Furthermore, this activity characterized backarc areas and is also affected, by extensional and strike-slip deformation, the zones along the southern European Margin. Despite the diffusion of volcaniclastic deposits, the recognized penecontemporaneous volcanic sources so far are limited. The calc-alkaline activity is considered to be geologically coeval with the active subduction, but in some cases (e.g., Mattioli et al. 2012 and references therein), a primary continental (Adria) volcanism occurs only during the $\mathrm{Ru}$ pelian pro parte ( 32 to $29 \mathrm{Ma})$. The climax of volcanic activity occurred in the early Miocene, related to the Aquitanian tectonic events responsible for the beginning of the orogenic building of the Betic, Maghrebian, and Apennine Chains. Acid-intermediate calc-alkaline volcanic products are recorded in different areas of the Betides, Maghrebides, and Apennines and in the Mediterranean Sea (e.g., the Valencia Trough) and the Corsica-Sardinia block (e.g., Duggen et al. 2005; Carminati et al. 2010, 2012; Lustrino et al. 2011, 2013; Savelli 2015). All these products may represent potential source areas for volcaniclastites, as inferred from their compatible age and geochemistry (Ryan et al. 1972; Bellon 1976, 1981; Bellon and Letouzey 1977; Coulon 1977; Savelli et al. 1979; Rivière et al. 1981; Bellon et al. 1983; Marignac and Zimmermann 1983; Penven and Zimmermann 1986; Hernandez et al. 1987; Rivière 1988; Mitjavila et al. 1990; Comas et al. 1992; Anelli et al. 1994; Belanteur et al. 1995; Assorgia et al. 1997; Morra et al. 1997; Rossi et al. 1998; Mattioli et al. 2000; Scotney et al. 2000; Chalouan et al. 2001; Downes et al. 2001; Mattioli et al. 2002; Duggen et al. 2004; Lustrino et al. 2009; Conte et al. 2010; Beccaluva et al. 2011, 2013; Lustrino et al. 2011; Réhault et al. 2012; table A2). 


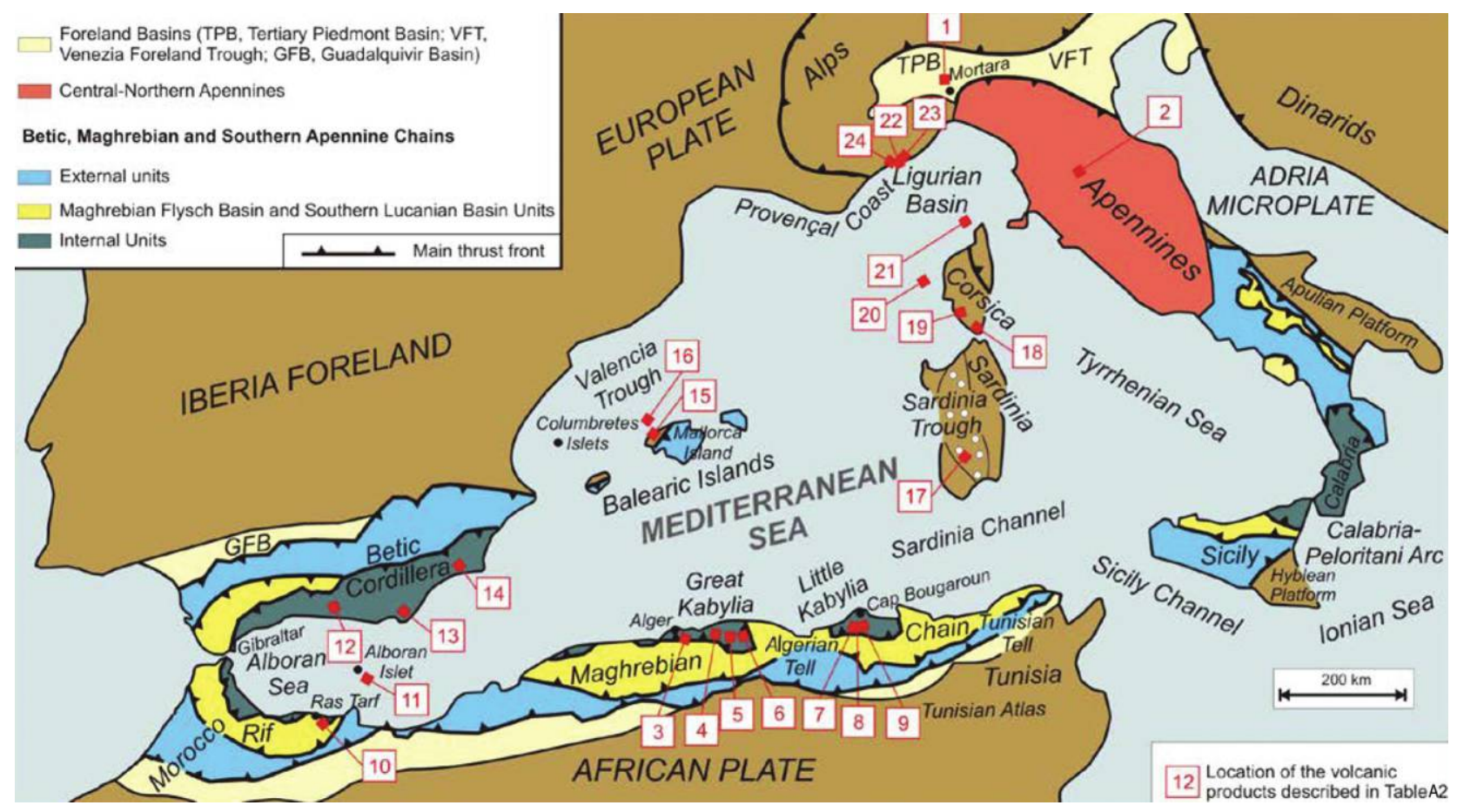

Figure 3. Distribution of the uppermost Chattian-Langhian volcanites in the tectonic provinces of the centralwestern Mediterranean area.

The volcanic activity, consisting of frequent highmagnitude eruptions, was generated in different geodynamic contexts: (1) subduction of the Africa-Adria plate beneath the European plate or beneath the intermediate microplate marked by different volcanic arc systems; (2) backarc basins of the BeticMaghrebian-Apennine systems (Valencia Trough, southwestern Corsica Margin, and Sardinia Trough and mainland), due to the rollback of the subduction slab; and (3) basins developed in a strike-slip fault zone context (eastern part of the Betic Cordillera during the middle-late Miocene).

\section{Resulting Geological Constraints and Discussion}

Paleogeographic Constraints. General features and distribution of volcaniclastic deposits present the following main constraints for paleotectonic and paleogeographic interpretations:

1. The wide distribution of volcaniclastic deposits implies the occurrence of multiple volcanic source areas located in different geotectonic provinces.

2. Volcaniclastites were often deposited in limited basin sectors and show thickness and grain-size variations, vertical variability of litho- and petrofacies, and very limited lateral continuity. These deposits indicate vertical and lateral variability of the volcanic supply and an irregular morphology of depositional areas that acts as a "trap basin" for reworked sediments.

3. Some indicators such as thickness, grain size, very poor continuity, and lateral correlations of volcaniclastic beds argue in favor of a distance between volcanic sources and depositional areas that is not excessive, as can be inferred in comparison to paleogeographical-geodynamic models. In particular, the occurrence in some sectors of very thick volcaniclastic reworked deposits (e.g., the Tusa Flysch in Sicily and the southern Apennines and the Bisciaro Formation in the UmbriaMarche Apennines) supports this hypothesis (e.g., de Capoa et al. 2002; Guerrera et al. 2004, 2015; Perri et al. 2012).

4. As verified in different successions (e.g., Algerian Tell and external Betic units), when the values of the previous indicators (thickness, grain size, and continuity) in marine successions are high, the presence of pyroclasts-epiclasts in original emplacements is very likely. Moreover, it is noteworthy that in most of cases, both processes (redeposition and fallout) coexist in the same succession. This last observation suggests that in most cases, the source or basin distance is not discriminant for the emplacement processes.

5. Despite the great diffusion of volcaniclastic deposits, the original amount of volcanic material 
emitted had to be much larger and should have been drastically reduced mainly because of (1) high dispersion, especially during the fallout processes; (2) erosion and transport during redeposition; and (3) alteration and transformation processes during diagenetic phases.

Some parameters of volcaniclastites that are useful for quantitative evaluation are shown in table A3.

Volcano-tectonic Constraints. First, the available petrochemical data for volcaniclastic deposits confirmed the substantial penecontemporaneity between volcanism and marine sedimentary successions. The penecontemporaneity of the volcaniclastic products was deduced from specific mineralogical characteristics such as the freshness of certain paragenesis (e.g., feldspars) and the textural characteristics of volcanic glasses (unaltered and with intact edges). More generally, the correlation at small and large scales (formations of the same basin context or between different basins) and the connection between primary and secondary products was deduced through the definition of geodynamic events on a regional scale. In fact, in the Miocene history of periMediterranean chains, different volcanic and volcanogenic events, even of regional extension, are well identified. The current state of knowledge is sometimes lacking in various analytical aspects (e.g., geochemical analysis) and does not yet allow us to specify, in a more rigorous way, a detailed picture of the phenomenology involved. The interdisciplinary study of volcanogenic deposits, in relation to primary volcanic events, also offers the opportunity to investigate the location of the original volcanic areas and thus to formulate compatible paleogeographic and paleotectonic models. Finally, the wide distribution of volcaniclastic deposits needs the presence of multiple magmatic sources because a single source area, even if extensive, cannot be sufficient to justify the amount present in the peri-Mediterranean chains.

Second, calc-alkaline magmatism is related to geodynamic processes linked to convergent plate margins and subductions during the latest ChattianLanghian ( 26 to $15 \mathrm{Ma}$ ) early stages of the building of the Betic, Maghrebian, and Apennine Chains. This magmatism constitutes a potential source of volcanoclastic deposits listed in table A1.

Third, acid-intermediate volcanism, located in the eight provinces listed in table A2, also constitutes a potential source of volcanoclastic deposits listed in table A1.

Fourth, it is necessary to identify the different volcanic districts generating products compatible with volcaniclastic deposits and, at the same time, to define the emplacement processes.
The known volcanites, which represent remnants of widespread regional magmatic activity, do not seem to be sufficient to justify the abundance of volcaniclastic deposits. However, the severe alteration and erosion of the poorly resistant volcanic sources, the development of convergence and subduction processes, the burial by thrusting and "cannibalization" related to fault-systems activity, and so forth, caused a rapid dismantling of the volcanic arcs that can explain this apparent anomaly. Instead, caution is required when interpreting the scarcity or absence of volcanites in some sectors (e.g., offshore from the Maghrebian Chain and Tunisian-Algerian Tell). In other sectors volcanic products are preserved, demonstrating a clearer relationship between the volcanic source and sedimentary basin (e.g., Sardinia Block). The volcanic source of the volcaniclastites of the Apennines and Sicily is more problematic.

The possible geodynamic events responsible for the volcanic activity (table A4) are (1) the subduction of the western Tethys oceanic lithosphere attached to the Adria microplate beneath the internal domain (Tuscanides) during the Miocene; (2) the subduction and consumption of the oceanic/ thinned crust of the Maghrebian Basin beneath the intermediate microplate during the Miocene (toward the north in Betic, Rif, and Tell zones; toward the west in Apennine zones due to the CalabriaPeloritani curvature of the subduction zone); and (3) the backarc basin opening (as a consequence of the above-mentioned subduction), as in the Valencia Trough and the Provençal Basin with differences in the speed accommodated by transform faults.

The evaluation of the distance between volcanoes and sedimentary basins is difficult for many reasons, especially because of the space and time variability in the magnitude of explosions. For this reason, it is better to analyze each single system and check for elements that can provide useful indications. Some correlations between sedimentary foreland basins with possible volcanic sources are (1) Sardinia Trough/western Sardinia volcanism, (2) Tertiary Piedmont Basin/Po Plain volcanism recognized in the Mortara 1 well, and (3) Bisciaro Basin/ Tuscany volcanism recognized in the Pieve Santo Stefano 1 well. These reconstructions could support models in which this distance could be constrained up to a maximum of $100-200 \mathrm{~km}$.

Regarding the Miocene volcaniclastic deposits of the southern Apennines and Sicily, most authors consider volcanism of western Sardinia as the source area (e.g., Perri et al. 2012; Critelli et al. 2013; 2017; Giordano et al. 2017). The volcanic centers that supplied local depositional units (e.g., Tusa Flysch and Troina and Poggio Santa Maria Sandstones in 
Sicily; Tusa Tuffites and Albanella-Corleto Sandstones in the southern Apennines; e.g., de Capoa et al. 2002; Guerrera et al. 2015, 2016) were probably related to volcanic arcs linked to subduction processes and consumption of oceanic basins (e.g., Maghrebian and Lucanian Basins). Taking into account some features of these formations (amount of volcanic products is up to $85 \%-90 \%$; frequent lava clasts, crystals, glass shards, pumices, thickness of a single volcaniclastic bed is up to $2 \mathrm{~m}$; grain size is up to $2.5 \mathrm{~mm}$; total thickness of volcaniclastic beds in a single succession is up to $200 \mathrm{~m}$; sediment redeposition processes, etc.), the volcanic arcs should be closer to the depositional areas. Consequently, excluding the European Margin, other solutions that provide adequate distances between volcanic arcs and basins and that are compatible with the characters of volcaniclastites should be proposed.

Moreover, several evolutionary models of the central-western Mediterranean consider the paleogeographic distance between the Sardinia-Corsica Block and the Apennine-Sicily Basins to have been several hundred kilometers or more in the early Miocene (e.g., Gueguen et al. 1998; Edel et al. 2001; Giordano et al. 2017). This would seem incompatible with the above-described features (mainly grain size) of volcaniclastites. In addition, the presence of important morphologic dams (i.e., the extension of the Alpine Chain of northern Corsica to the south) between the Sardinia-Corsica Block and the ApennineSicilian Basins introduces problems when considering Sardinia as the provenance area, which in different models is considered to be at least $500-600 \mathrm{~km}$ away from the different Apenninic basins containing volcaniclastites. In fact, the exceedingly large distance-in particular, the presence of submarine morphologic reliefs related to building the Alpine Chain-would not allow the passage of turbiditic sediments. Therefore, the presence of turbidite volcaniclastic deposits with the observed grain size is unlikely to have been possible. Also taking into account the paleogeographic models, which consider the presence of an intermediate microplate between the African and European plates (Doglioni 1992; Guerrera et al. 1993, 2005, 2007, 2012; Maillard and Mauffret 1993; de Capoa et al. 2002; Guerrera and Martín-Martín 2014; Amendola et al.2016), provenance from Sardinia seems difficult to admit. A relationship between pyroclastites and the primary Sardinia volcanism seems possible only for pyroclastic deposits, especially for those related to the large explosions that generated great volumes of the Sardinia ignimbrites (Assorgia et al. 1997). In fact, the role of the volcanism of the Sardinia-Corsica Block in the supply to the Miocene basins of the
Maghrebian-Apennine Chains is probably restricted to thin pyroclastic beds (fallout deposits) given the long distances according to the paleogeography from the supply point and the basin.

However, the Sardinia Trough, where the sedimentary basins with volcaniclastites are located / 50 to $100 \mathrm{~km}$ from the volcanic sources; e.g., the Marmilla Basin; Guerrera et al. 2004), may represent a realistic key case applicable elsewhere. A further comparable case is presented by the Bisciaro Formation (Adria Margin), where the distance between the volcanic source and the sedimentary basin was estimated to be less than $100 \mathrm{~km}$ (Guerrera et al. 2015). A similar approach in examining the proximity between source areas and sedimentary basins has been adopted in other sectors of the Apennines (Clari et al. 1988; Ruffini et al. 1995; D'Atri et al. 1999, 2001; de Capoa et al. 2002; Guerrera et al. 2015).

Figure 4 shows an evolutionary model based on the paleogeographic model by Guerrera and MartínMartín (2014). Three stages in the evolution (late Oligocene, early Miocene, and Langhian, respectively) are presented showing the possible position of source volcanic areas and sedimentary basins. In this figure, the main late Oligocene (fig. 4A), early Miocene (fig. 4B), and middle Miocene (fig. 4C) geodynamic features, postdating the Eo-Alpine and NeoAlpine history, are noted. The syn-orogenic volcanic activity and related volcaniclastites occur in very few areas (tables A1, A2; figs. 2, 3). In fact, the volcanic activity is restricted to the southern and eastern margins of the intermediate microplate (subduction zone), located between the European and AfricaAdria plates, and in the Valencia Trough (rifting). In figure $4 A$, the distribution (fig. 2) of the late Oligocene volcaniclastites (table A1; fig. 2) is reported. In this period only a few volcaniclastites and a possible volcanic source point are documented. In figure $4 B$, the maximum distribution (fig. 2) of the AquitanianBurdigalian volcaniclastites (table A1; fig. 2) and the climax of the volcanism are reported; in addition, a geodynamic evolutionary phase of the centralwestern Mediterranean chain systems is shown. In our interpretation, the volcanic source areas are prevalently located along the margins of the abovementioned terrane or intermediate microplate (volcanic arcs systems), in the Adria Margin (continental collision), the Corsica-Sardinia Block (backarc zone), and the Valencia Trough-Ligurian Basin (rifting). In the last stage (fig. 4C), the distribution of volcaniclastites during the Langhian is presented. A marked reduction of volcanic products and volcaniclastites is recorded (tables A1, A2; figs. 2, 3). In this last time interval, the volcanic source areas are located mainly 

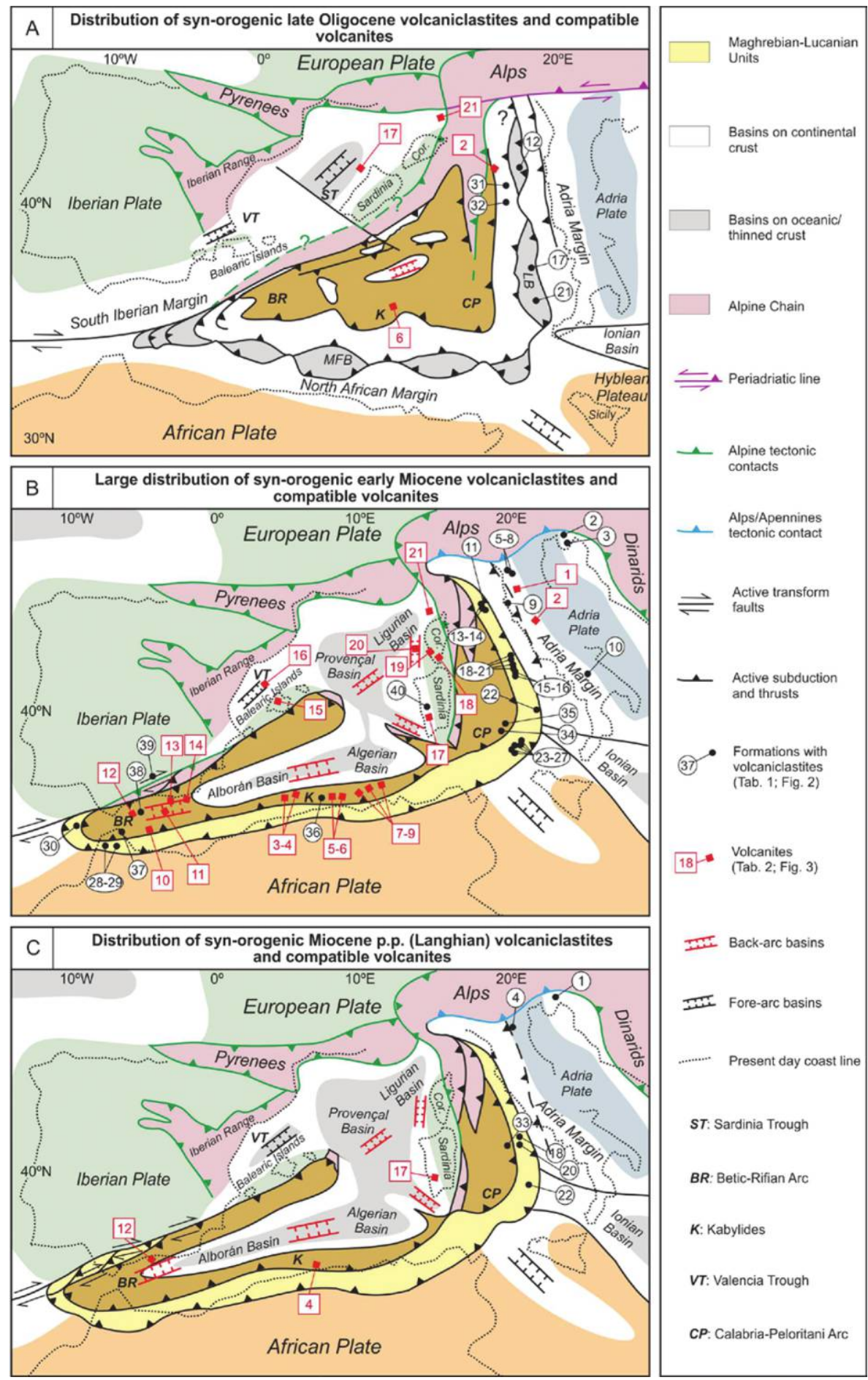

Figure 4. Paleogeographic and paleotectonic evolutionary model of the central-western Mediterranean region sketched in four steps (Schettino and Turco 2006, 2011 and Guerrera and Martín-Martín 2014; modified). A, Late Oligocene. B, Early Miocene. C, Middle Miocene pro parte (Langhian). The relationships between sedimentary basins and volcaniclastites, and the distribution of active volcanic systems during the late Oligocene-middle Miocene pro parte (Langhian) are shown. 
in the Corsica-Sardinia Block and near the Alboran Basin (backarc zones). The different geotectonic contexts and recognized geodynamic processes are summarized in table A4.

\section{Final Remarks}

In our opinion, the occurrence of volcanosedimentary successions marks geodynamic events that impose constraints for the paleogeographic and paleotectonic reconstructions.

Regarding the central-western Mediterranean region, the abundant uppermost Chattian-Langhian volcaniclastic deposits are penecontemporaneous with an acid-intermediate and calc-alkaline orogenic magmatism showing a climax during the early Miocene. Eight different geotectonic provinces marked by variable volcanic products derived from this volcanism were recognized.

Volcaniclastites are grouped in three main types interbedded within marine successions: (1) pyroclastic deposits, (2) mixed pyroclastic-epiclastic deposits, and (3) epiclastic deposits mixed with marine deposits. Redeposited volcaniclastic beds are more frequent and thicker than fallout deposits. However, most frequent volcaniclastites are represented by tuffites.

Volcaniclastic deposits provide significant indications of both the distance of volcanic source areabasin and the physiography of depositional basins. In particular, the distribution, thickness, and grain size of redeposited materials imply the absence of morphological barriers (i.e., continuous morphological ridges, submarine reliefs or orogens) between source areas and basins. In addition, the thickness and grain size of pyroclastic deposits, which decrease rapidly when receding from volcanic centers, indicate a short distance between volcanic source and basins. In particular, the grain size of volcaniclastites normally ranges from fine- or medium-grained sand to coarse-grained sand, whereas the thickness, in some cases, reaches several meters, suggesting provenance from areas not far away.

The scarcity of primary volcanic products makes it difficult to define the direct relationship between volcanic centers and sedimentary basins, thereby making all reconstructions strongly dependent on the adopted geodynamic model. However, in the Sardinia Trough, the closeness of basin areas and volcanic districts is still recognizable. Taking into consideration the general sedimentary features of the studied volcaniclastites, in our opinion, this case may represent a basic model for interpretation of the relationships between volcanic sources and secondary products and may permit interpretations for other sectors (e.g., Bisciaro Basin, northern Apennines, Tertiary Piemontese Basin, etc.).

In conclusion, we believe that the volcaniclastic deposition in the central-western Mediterranean area occurred much closer, regarding the volcanic centers, than is considered today (i.e., the southern margin of the European plate). In fact, the presence of the young Alpine Chain between the European Continental Margin and the depositional areas of volcaniclastites in the late Oligocene-early Miocene would have made the turbiditic feeding impossible. For this reason, the volcanic detritus had to be provided by volcanoes related to the nearby subduction zone. This subduction area could be the eastern margin of a microplate located between the Eo-Alpine Chain and the Neo-Alpine BeticMaghrebian-Apennine system, the presence of which has long been hypothesized in the literature. Several possible sources of supply of volcaniclastic material are located in the three stages of the evolutionary model displayed in figure 4. Our interpretation suggests that during the latest Chattian-Langhian period, the central-western Mediterranean region was characterized by a complex geodynamic framework with different subduction zones and resulting opening backarc basins. The resulting different tectonic elements were included in the Betic-MaghrebianApennine orogens to constitute the internal zones (e.g., the Betic-Rifian and Calabria-Peloritani Arcs).

The space-time evolution of the central-western Mediterranean volcaniclastites provides keys for recognizing interconnected geodynamic events (e.g., volcanic activity) and sedimentary and tectonic events and interpreting them in a more coherent paleogeographic-paleotectonic framework. The proposed interpretations should be considered as a preliminary contribution to this complex topic, which needs further interdisciplinary investigation, especially the petrochemical characterization of volcaniclastites.

\section{A C K N O W LED G M E N T S}

Research was supported by grants from the University of Urbino to F. Guerrera and M. Tramontana; by the CGL2016-75679-P research project (Spanish Ministry of Education and Science); and by research groups and projects of the Generalitat Valenciana from Alicante University. The review performed by three anonymous reviewers is acknowledged. 


\section{REFERENCES CITED}

Alagna, K. E.; Peccerillo, A.; Martin, S.; and Donati, C. 2010. Tertiary to present evolution of orogenic magmatism in Italy. J. Virtual Expl. 36:18. https://doi.org /10.3809/jvirtex.2010.00233.

Amendola, U.; Perri, F.; Critelli, S.; Monaco, P.; Cirilli, S.; Trecci, T.; and Rettori, R. 2016. Composition and provenance of the Macigno Formation (late Oligoceneearly Miocene) in the Trasimeno Lake area (northern Apennines). Mar. Pet. Geol. 69:146-167.

Anelli, L.; Gorza, M.; Pieri, M.; and Riva, M. 1994. Surface well data in the northern Apennines (Italy). Mem. Soc. Geol. Ital. 48:461-471.

Assorgia, A.; Barca, S.; and Spano, C. 1997. A synthesis on the Cenozoic stratigraphic, tectonic and volcanic evolution in Sardinia (Italy). Boll. Soc. Geol. Ital. 116:407420.

Balogh, K.; Delle Rose, M.; Guerrera, F.; Moretti, E.; Ravasz-Baranyai, L.; Serrano, F.; Rusciadelli, G.; Veneri, F.; and Viczian, I. 1992. Stratigraphic and volcaniclastic events in the Vicchio Marl Formation (Tuscan Nappe) along the Montefatucchio section (northern Apennines, Italy). In Montanari, A.; Coccioni, R.; and Odin, G. S., eds. Interdisciplinary Geological Conference on the Miocene Epoch with Emphasis on the UmbriaMarche Sequence (November 15, 1992), Proc. Ancona, Italy, Int. Union Geol. Sci., p. 18-20.

Balogh, K.; Guerrera, F.; Ravasc-Baranyai, L.; and Veneri, F. 1993. New data concerning the inframiocenic "Bisciaro volcaniclastic event" (Umbro-Marche Apennines) and comparison with similar occurrences. G. Geol. 55:83104.

Beccaluva, L.; Bianchini, G.; Mameli, P.; and Natali, C. 2013. Miocene shoshonite volcanism in Sardinia: implications for magma sources and geodynamic evolution of the central-western Mediterranean. Lithos 180-181:128-137.

Beccaluva, L.; Bianchini, G.; Natali, C.; and Siena, F. 2011. Geodynamic control on orogenic and anorogenic magmatic phases in Sardinia and southern Spain: inferences for the Cenozoic evolution of the western Mediterranean. Lithos 123:218-224.

Belanteur, O.; Bellon, H.; Maury, R.C.; Ouabadi, A.; Coutelle, A.; Semroud, B.; Megartsi, M.; and Fourcade, S. 1995. Le magmatisme miocène de l'Est Algérois, géologie, géochimie et géochronologie ${ }^{40} \mathrm{~K}-{ }^{40} \mathrm{Ar}$. C. R. Acad. Sci. Paris, ser. IIa, 321:489-496.

Bellon, H. 1976. Séries magmatiques néogènes et quaternaires du pourtout de la Méditerranée occidentale, comparées dans leur cadre géologique. Implications géodynamiques. Thèse d'Etat, Université Paris-Sud, Orsay.

- 1981. Chronologie radiometrique (K-Ar) des manifestations magmatiques autour de la Méditerranée occidentale entre 33 et 1 Ma. In Wezel, F. C., ed. Sedimentary basins of Mediterranean margins. CNR Italian Project of Oceanography. Bologna, Tecnoprint, p. 341360.
Bellon, H.; Bordet, P.; and Montenat, C. 1983. Chronologie du magmatisme néogène des cordillères bétiques (Espagne meridionale). Bull. Soc. Geol. Fr., ser. 7, 25:205217.

Bellon, H., and Letouzey, J. 1977. Volcanism related to plate-tectonics in the western and eastern mediterranean. In International Symposium on Structural History of the Mediterranean Basins (Split, 1977), Proc., p. 165184.

Best, M. G. 2003. Igneous and metamorphic petrology. Oxford, Blackwell Science, 729 p.

Bonardi, G.; de Capoa, P.; Di Staso, A.; Estevez, A.; MartínMartín, M.; Martín-Rojas, I.; Perrone, V.; and TentManclús, J. E. 2003. Oligocene to early Miocene depositional and structural evolution of the CalabriaPeloritani Arc southern terrane (Italy) and geodynamic correlations with the Spain Betics and Morocco Rif. Geodin. Acta 16:149-169.

Bonci, M. C.; Cortesogno, L.; Gaggero, L.; Negri, A.; and Pirini Radrizzani, C. 1994. Preliminary data on the Oligo-Miocene volcanism in the Garbagna area $\left(\mathrm{AL}, \mathrm{F}^{\circ}\right.$ Voghera). Atti Ticinensi Sci. Terra (spec. ser.), p. 283 296.

Borsetti, A. M.; Cati, F.; Mezzetti, R.; Savelli, C.; and Toni, G. 1984. Le intercalazioni vulcanoclastiche nei sedimenti oligo-miocenici dell'Appennino settentrionale e centrale (dati petrologici, K/Ar e micropaleontologici). G. Geol. 45/2:159-198.

Boulin, J.; Bourgois, J.; Chauve, P.; Duran Delga, M.; Magné, J.; Mathis, V.; Peyre, Y.; Rivière, M.; and Vera, J.A. 1973. Age miocène inférieur de la formation de la Viñuela, discordante sur les nappes internes bétiques (Province de Malaga, Espagne). C. R. Acad. Sci. Paris 276:1245-1248.

Bouma, A. H. 1962. Sedimentology of some flysch depositis. Elsevier, Amsterdam, $168 \mathrm{p}$.

Cammarosano, A.; Cavuoto, G.; Danna, M.; De Capoa, P.; De Rienzo, F.; Di Staso, A.; Giardino, S.; et al. 2004. Nuovi dati sui flysch del Cilento (Appennino meridionale, Italia). Boll. Soc. Geol. Ital. 123:253-273.

Carminati, E., and Doglioni, C. 2012. Alps vs. Apennines: the paradigm of a tectonically asymmetric Earth. EarthSci. Rev. 112:67-96.

Carminati, E.; Lustrino, M.; Cuffaro, M.; and Doglioni, C. 2010. Tectonics, magmatism and geodynamics of Italy: what we know and what we imagine. J. Virtual Expl. 6:9. https://doi.org/10.3809/jvirtex.2010.00226.

Carminati, E.; Lustrino, M.; and Doglioni, C. 2012. Geodynamic evolution of the central western Mediterranean: tectonics vs. igneous petrology constraints. Tectonophysics 579:173-192.

Carmisciano, R.; Coccioni, R.; Corradini, D.; D'Alessandro, A.; Guerrera, F.; Loiacono, F.; Moretti, E.; Puglisi, D.; and Sabato, L. 1989. Nuovi dati sulle "Successioni Miste" inframioceniche dell'Algeria (Grande Kabilia) e della Sicilia (Monti Nebrodi): confronti con analoghe 
successioni torbiditiche nell'Arco di Gibilterra e nell'Appennino lucano. Mem. Soc. Geol. Ital. 38:551-576.

Chalouan, A.; Michard, A.; Feinberg, H.; Montigny, R.; and Saddiqi, O. 2001. The Rif Mountain building (Morocco): a new tectonic scenario. Bull. Soc. Geol. Fr. 172: 603-616.

Chauve, P.; Mathis, V.; Peyre, Y.; and Rivière, M. 1973. Sur la présence de tufs dans les sédiments d'âge burdigalien de la région de Viñuela-Alcaucin-Zafarraya-Riogordo (Province de Malaga, Espagne méridionale). Ann. Sci. Univ. Besancon 20:153-165.

Chiocchini, U.; Franchi, R.; Guerrera, F.; Ryan, W. B. F.; and Vannucci, S. 1978. Geologia di alcune successioni torbiditiche cretaceo-terziarie appartenenti ai "Flysch Maurétaniens" e alla "Nappe Numidienne" del Rif settentrionale (Marocco). Studi Geol. Camerti 4:37-65.

Clari, P.; Pirini, C.; Ricci, B.; Ruffini, R.; and Valleri, G. 1988. Livelli cineritici miocenici nel Monferrato. Rend. Soc. Geol. Ital. 11:293-296.

Comas, M. C.; Garcia-Duenas, V.; and Jurado, M. J. 1992. Neogene tectonic evolution of the Alboran Sea from MCS data. Geo-Mar. Lett. 12:157-164.

Conte, A. M.; Palladino, D. M.; Perinelli, C.; and Argenti, E. 2010. Petrogenesis of the high-alumina basalt-andesite suite from Sant'Antioco Island, SW Sardinia, Italy. Period. Mineral. 79:27-55.

Cornamusini, G. 2002. Compositional evolution of the Macigno Fm. of southern Tuscany along a transect from the Tuscan coast to the Chianti Hills. Boll. Soc. Geol. Ital. vol. spec. 1:365-374.

Coulon, C. 1977. Le volcanisme calco-alcalin cénozoique de Sardaigne (Italie): pétrographie, géochimie et genèse des laves andesitiques et des ignimbrites. Signification geodynamique. Thèse d'Etat, Université Marseille.

Critelli, S. 1991. Evoluzione delle mode detritiche delle successioni arenitiche terziarie dell'Appennino meridionale. Mem. Soc. Geol. Ital. 47:55-93.

Critelli, S., and Le Pera, E. 1990. Litostratigrafia e composizione della Formazione di Pollica (Gruppo del Cilento, Appennino meridionale). Boll. Soc. Geol. Ital. 109:511-536.

Critelli, S., and Monaco, C. 1993. Depositi vulcanoclastici nell'Unità del Flysch Calabro-Lucano (Complesso Liguride, Appennino meridionale). Boll. Soc. Geol. Ital. 112:121-32.

Critelli, S.; Muto, F.; Perri, F.; and Tripodi, V. 2017. Interpreting provenance relations from sandstone detrital modes, southern Italy foreland region: stratigraphic record of the Miocene tectonic evolution. Mar. Pet. Geol. 87:2-14.

Critelli, S.; Muto, F.; Tripodi, V.; and Perri, F. 2013. Link between thrust tectonics and sedimentation processes of stratigraphic sequences from the southern Apennines foreland basin system, Italy. Rend. Online Soc. Geol. Ital. 25:21-42.

D'Atri, A.; Dela Pierre, F.; Lanza, R.; and Ruffini, R. 1999. Distinguishing primary and resedimented vitric volcaniclastic layers in the Burdigalian carbonate shell deposits in Monferrato (NW Italy). Sediment. Geol. 129:143-163.
D'Atri, A.; Dela Pierre, F.; Ruffini, R.; Novaretti, A.; Cosca, A. M.; and Hunziker, J. C. 2001. Calcareous plankton biostratigraphy and ${ }^{40} \mathrm{Ar} /{ }^{39} \mathrm{Ar}$ dating of Miocene volcaniclastic layers from Monferrato (NW Italy). Eclogae geol. Helv. 94:137-144.

D'Atri, A., and Tateo, F. 1994. Volcano-sedimentary beds of Oligocene age from the Tertiary Piedmont Basin (NW Italy): biostratigraphy and mineralogy. G. Geol. 56:79-95.

de Capoa, P.; Di Staso, A.; Guerrera, F.; Perrone, V.; and Tramontana, M. 2003. The extension of the Maghrebian Flysch Basin in the Apenninic Chain: paleogeographic and paleotectonic implications. Trav. Inst. Sci. Rabat Geogr. Phys. 21:77-92.

- 2004. The age of the oceanic accretionary wedge and continental collision in the Sicilian sector of the Maghrebian Chain. Geodin. Acta 17:331-348.

de Capoa, P.; Di Staso, A.; Guerrera, F.; Perrone, V.; Tramontana, M.; and Zaghloul, M. N. 2002. The lower Miocene volcaniclastic sedimentation in the Sicilian sector of the Maghrebian Flysch Basin: geodynamic implications. Geodin. Acta 15:141-157.

Delfrati, L.; Falorni, P.; Izzo, P.; and Petti, F. M. 2003. Carta geologica d'Italia-1:50.000: catalogo delle formazioni. Commissione Italiana di Stratigrafia della Società Geologica Italiana. Quaderni serie III, 7. Rome, APAT (Agenzia per la Protezione dell'Ambiente e per i Servizi Tecnici), $210 \mathrm{p}$.

Di Staso, A., and Giardino, S. 2002. New integrate biostratigraphic data about the Saraceno Formation (NorthCalabrian Unit; southern Apennines). Boll. Soc. Geol. Ital. vol. spec. 1:517-526.

Doglioni, C. 1992. Main differences between thrust belts. Terra Nova 4:152-164.

Downes, H.; Thirlwall, M. F.; and Trayhorn, S. C. 2001. Miocene subduction-related magmatism in southern Sardinia: Sr-Nd- and oxygen isotopic evidence for mantle source enrichment. J. Volcanol. Geotherm. Res. 106:1-21.

Duggen, S.; Hoernle, K.; van den Bogaard, P.; and GarbeSchonberg, D. 2005. Post-collisional transition from subduction- to intraplate-type magmatism in the westernmost Mediterranean: evidence for continental-edge delamination of subcontinental lithosphere. I. Petrol. 46:1155-1201.

Duggen, S.; Hoernle, K.; van den Bogaard, P.; and Harris, C. 2004. Magmatic evolution of the Alboran region: the role of the subduction in forming the western Mediterranean and causing the Messinian salinity crisis. Earth Planet. Sci. Lett. 218:91-108.

Durand Delga, M. 1980. La Méditerranée occidentale: étapes de sa genèse et problèmes structuraux liés à celle-ci. Livre Jub. Soc. Geol. Fr., Mem. hors ser., 10:203-224.

Durand Delga, M., and Fontboté, J. M. 1980. Le cadre structural de la Méditerranée occidentale. Mem. Bur. Rech. Geol. Min. (Serv. Geol. Natl.) 115:67-85.

Edel, J. B.; Dubois, D.; Marchant, R.; Hernandez, J.; and Cosca, M. 2001. La rotation miocène inférieur du bloc corso-sardo. Nouvelles contraintes paléomagnetiques 
sur la fin du movement. Bull. Soc. Geol. Fr. 172:275283.

Faugères, J. C.; Broquet, P.; Duée, G.; and Imbert, P. 1992. Episodes volcano-sédimentaires et paléo-courants dans le Numidien externe de Sicile: les tuffites et contourites de Karsa. C. R. Acad. Sci. Paris 315:479-486.

Feinberg, H.; Maaté, A.; Bouhdadi, S.; Duran Delga, M.; Maaté, M.; Magné, J.; and Olivier, P. 1990. Signification des dépôts de l'Oligocène supérieur et du Miocène inférieur du Rif interne (Maroc) dans l'évolution géodynamique de l'Arc du Gibraltar. C. R. Acad. Sci. Paris 310:1487-1495.

Frizon de Lamotte, D.; Saint Bezar, B.; and Bracène, R. 2000. The two main steps of the Atlas building and geodynamics of the western Mediterranean. Tectonics 19:740-761.

Giammetti, F.; Mezzadri, G.; and Papani, G. 1968. Le intercalazioni cineritiche di M. Varano. Ateneo Parmense Acta Nat. 4(4):3-28.

Gianello, A., and Gottardi, G. 1969. Sulla zeolizzazione del livello cineritico detto "Tripoli di Contignaco." Mineral. Petrogr. Acta 15:5-8.

Giordano, R.; Caggianelli, A.; Sulpizio, R.; Balestrieri, M. L.; Maiorano, P.; and Solari, L. 2017. Magmatic and geodynamic significance of two volcaniclastic deposits in the Oligo-Miocene successions of the southern Apennines (Italy). Ital. J. Geosci.136:157-170.

González Donoso, J. M.; Linares, D.; Molina, E.; Serrano, F., and Vera, J. A. 1982. Sobre la edad de la formacion de la Viñuela (Cordilleras Béticas, provincia de Malaga). Bol. R. Soc. Esp. Hist. Nat. (Geol.) 80:255-275.

Grandesso, P., and Stefani, C. 1990. Volcanic contributions to sedimentation in upper Burdigalian-lower Langhian sediments of the Venetian molassic basin. Riv. Ital. Pal. Strat. 96/2-3:337-350.

Gueguen, E.; Doglioni, C.; and Fernandez, M. 1998. On the post-25 Ma geodynamic evolution of the western Mediterranean. Tectonophysics 298:259-269.

Guerrera, F.; Martín-Algarra, A.; and Martín-Martín, M. 2012. Tectono-sedimentary evolution of the "Numidian Formation" and lateral facies (southern branch of the western Tethys): constraints for central-western Mediterranean geodynamics. Terra Nova 24:34-41.

Guerrera, F.; Martin-Algarra, A.; and Perrone, V. 1992. Syn-late-orogenic successions in western-central Mediterranean chains during late Oligocene-Miocene time. Int. Geol. Cong., 29th (Kyoto, August 24-September 3), Proc. 1:22.

1993. Late Oligocene-Miocene syn-/late-orogenic successions in western and central Mediterranean chains from the Betic Cordillera to the southern Apennines. Terra Nova 5:525-544.

Guerrera, F., and Martín-Martín, M. 2014. Geodynamic events reconstructed in the Betic, Maghrebian, and Apennine Chains (central-western Tethys). Bull. Soc. Geol. Fr. 185:329-341.

Guerrera, F.; Martín-Martín, M.; Perrone V.; and Tramontana, M. 2005. Tectono-sedimentary evolution of the southern branch of the western Tethys (Magrebian
Flysch Basin and Lucanian Ocean). Terra Nova 17:358367.

Guerrera F.; Martín-Martín, M.; Raffaelli, G., and Tramontana, M. 2015. The early Miocene "Bisciaro volcaniclastic event" (northern Apennines, Italy): a key study for the geodynamic evolution of the centralwestern Mediterranean. Int. I. Earth Sci. 104:10831106. https://doi.org/10.1007/s00531-014-1131-5.

. 2016. Volcaniclastites as a key for geodynamic constraints in the evolution of the central-western Mediterranean region: an overview. Asian Acad. Res. J. Multidiscip. 3:179-217.

Guerrera, F.; Martín-Martín, M.; and Tramontana, M. 2007. Principali eventi geodinamici e stadi evolutivi nel sub-Dominio "Mauretaniano" (Bacino dei Flysch del Maghreb) nelle catene sud-alpine del Mediterraneo centro-occidentale. Rend. Soc. Geol. Ital. 4:234-236.

Guerrera, F.; Mattioli, M.; Serrano, F.; Tramontana, M.; and Raffaelli, G. 2004. Stratigraphy of the Miocene syn-rift volcano-sedimentary succession in a sector of the central-southern Sardinia Trough (Italy). Geol. Carpath. 55:51-63.

Handy, M. R.; Schmid, S. M.; Bousquet, R.; Kissling, E.; and Bernoulli, D. 2010. Reconciling plate-tectonic reconstructions of Alpine Tethys with the geologicalgeophysical record of spreading and subduction in the Alps. Earth-Sci. Rev. 102:121-158.

Hernandez, J.; De Larouziere, F. D.; Bolze, J.; and Bordet, P. 1987. Le magmatisme néogène bético-rifain et le couloir de décrochement trans-Alboran. Bull. Soc. Geol. Fr., ser. 8, 3(2):257-267.

Hlila, R.; Chalouan, A.; El Kadiri, K.; Sanz de Galdeano, C.; Martín-Pérez J. A.; Serrano, F.; López Garrido, A. C.; Maaté, A.; and Guerra-Merchán, A. 2008. New stratigraphic data of the Oligo-Miocene transgressive cover of the Ghomaride units (northern internal Rif, Morocco): implications on tectonosedimentary evolution. Rev. Soc. Geol. Esp. 21/1-2: 59-71.

Hoyez, B., and Andreieff, P. 1975. Présence d'une série turbiditique à débris pyroclastiques associée au Numidien de la Région de Gangi-Nicosia (Sicilie). III Réunion Annuelle des Sciences de la Terre (Montpellier, April 23-25), Proc., p. 197.

Le Maître, R. W. 2002. Igneous rocks: a classification and glossary of terms. Cambridge, Cambridge University Press, $236 \mathrm{p}$.

Lustrino, M.; Duggen, S.; and Roserberg, C. 2011. The central-western Mediterranean: anomalous igneous activity in an anomalous collision tectonic setting. Earth-Sci. Rev. 104:1-40.

Lustrino, M.; Fedele, L.; Melluso, L.; Morra, V.; Ronga, F.; Geldmacher, J.; Duggen, S.; et al. 2013. Origin and evolution of Cenozoic magmatism of Sardinia (Italy): a combined isotopic (Sr-Nd-Pb-O-Hf-Os) and petrological view. Lithos 180-181:138-158.

Lustrino, M.; Morra, V.; Fedele, L.; and Franciosi, L. 2009. Beginning of the Apennine subduction system in central western Mediterranean: constraints from Cenozoic "orogenic" magmatic activity of Sardinia, Italy. 
Tectonics, 28:TC5016. https://doi.org/10.1029/2008TC 002419.

Maaté, A.; Martin-Pérez, J. A.; Martín-Algarra, A.; Serrano, F.; Aguado, R.; Martín-Marín, M.; and El Hajjaji, K. 1995. Le Burdigalien inférieur de Boujarrah (Rif septentrional, Maroc) et la signification paléotectonique des séries miocènes transgressives sur les zones internes bético-rifaines. C. R. Acad. Sci. Paris 320:15-22.

Maillard, A., and Mauffret, A. 1993. Structure et volcanisme de la fosse de Valence (Méditerranée nordoccidentale). Bull. Soc. Geol. Fr. 164:365-383.

Marignac, C., and Zimmermann, J. L. 1983. Ages K-Ar de l'événement hydrothermal et des intrusions associées dans le district minéralisé miocène d'Aiñ Barbar (Est Constantinois, Algérie). Miner. Depos. 18:457-467.

Martín-Algarra, A. 1987. Evolución geologíca alpina del contacto entre las Zonas Internas y las Zonas Externas de la Cordillera Bética. Tesis, Univ. Granada, Publ. Dpto. Estratigrafía y Paleontología, 1171 p.

Martín-Martín, M.; Rey, J.; Alcalá, F.J.; Tosquella, J.; Deramond, J.; Lara-Corrona, E.; Duranthon, F.; and Antoine P. O. 2001. Tectonic controls on the deposits of a foreland basin: an example from the Eocene Corbières-Minervois basin, France. Basin Res. 13:419-433.

Mattioli, M.; Di Battistini, G.; and Zanzucchi, G. 2002. Petrology, geochemistry and age of the volcanic clasts from the Canetolo Unit (northern Apennines, Italy). Boll. Soc. Geol. Ital. vol. spec. 1: 399-416.

Mattioli, M.; Guerrera, F.; Tramontana, M.; Raffaelli, G.; and D'Atri, M. 2000. High-Mg tertiary basalts in southern Sardinia (Italy). Earth Planet. Sci. Lett. 179:1-7.

Mattioli, M.; Lustrino, M.; Ronca, S.; and Bianchini G. 2012. Alpine subduction imprint in Apennine volcaniclastic rocks: geochemical-petrographic constraints and geodynamic implications from early Oligocene Aveto-Petrignacola Formation (N Italy). Lithos 134135:201-220.

Michard, A.; Chalouan, A.; Feinberg, H.; Goffé, B.; and Montigny, R. 2002. How does the Alpine belt end between Spain and Morocco? Bull. Soc. Geol Fr. 173:3-15.

Mitjavila, J.; Ramos, E.; and Martì, J. 1990. Les ignimbrites del Puig de l'Ofre (Sierra de Tramontana, Mallorca): nouvelles précisions géologiques sur leur position et datation radiométrique. C. R. Acad. Sci. Paris 311:687-692.

Morra, V.; Secchi, F. A. G.; Melluso, L.; and Franciosi, L. 1997. High-Mg subduction-related Tertiary basalts in Sardinia, Italy. Lithos 40:69-91.

Papini, M., and Vannucci, S. 1993. Intercalazioni vulcanoclastiche e silicee nelle Arenarie del Cervarola del versante orientale di M. Giovi (Firenze). G. Geol. 55:51-69.

Patacca, E.; Scandone, P.; Bellatalla, M.; Perilli, N.; and Santini, U. 1992. The Numidian-sand event in the southern Apennines. Memorie Società Geologica Padova 43:297-337.

Penven, M. J., and Zimmermann, J. L. 1986. Mise en évidence, par la méthode potassium-argon, d"un âge langhian pour le plutonisme calco-alcaline de la Kabylie de Collo (Algérie). C. R. Acad. Sci. Paris 303:403-406.
Perri, F.; Critelli, S.; Cavalcante, F.; Mongelli, G.; Dominici, R.; Sonnino, M.; and De Rosa, R. 2012. Provenance signatures for the Miocene volcaniclastic succession of the Tufiti di Tusa Formation, southern Apennines, Italy. Geol. Mag. 149(3):423-442.

Perri, F.; Critelli, S.; Martín-Algarra, A.; Martín-Martín, M.; Perrone, V.; Mongelli, G.; and Zattin, M. 2013. Triassic redbeds in the Malaguide Complex (Betic Cordillera-Spain): petrography, geochemistry and geodynamic implications. Earth-Sci. Rev. 117:1-28.

Perrone, V. 1987. I depositi miocenici della dorsale di Monte Soprano (Appennino campano): segnalazione di vulcanismo andesitico e nuova interpretazione. Boll. Soc. Geol. Ital. 106:3-12.

Pescatore, T.; Di Nocera, S.; and Matano, F. 2012. Note illustrative della carta geologica d'Italia alla scala 1:50.000. Foglio 470: Potenza. http://www.isprambiente .gov.it/Media/carg/note_illustrative/470_Potenza.pdf.

Pieri, P., and Rapisardi, L. 1973. Su alcune grovacche vulcaniche dell'Appennino dauno. Boll. Soc. Sci. Nat. Napoli 82:191-210.

Poli, M. E.; Zanferrari, A.; Avigliano, R.; Grandesso, P.; Monegato, G.; Paiero, G.; and Stefani, C. 2007. Note illustrative della carta geologica d'Italia alla scala 1:50.000. Foglio 065: Maniago. http://www.isprambiente .gov.it/Media/carg/note_illustrative/65_Maniago.pdf.

Puga, E.; Díaz de Federico, A.; Fanning, M.; Nieto, J. M.; Rodríguez Martínez-Conde, J. A.; Díaz Puga, M. A.; Lozano, J. A.; Bianchini, G.; Natali, C.; and Beccaluva, L. 2017. The Betic ophiolites and the Mesozoic evolution of the western Tethys. Geosciences 7(2):31. https:// doi.org/10.3390/geosciences7020031.

Puglisi, D., and Carmisciano, R. 1992. Il Flysch di Algeciras (Oligocene-Miocene inf.?, Cordigliera betica): studio petrografico-sedimentologico e confronti con altre unità torbiditiche della catena maghrebide. Boll. Accad. Gioenia 25(340):5-23.

Réhault, J.-P.; Honthaas, C.; Guennoc, P.; Bellon, H.; Ruffet, G.; Cotten, J.; Sosson, M.; and Maury, R. C. 2012. Offshore Oligo-Miocene volcanic fields within the Corsica-Liguria Basin: magmatic diversity and slab evolution in the western Mediterranean Sea. I. Geodyn. 58:73-95.

Rivière, M. 1988. Sédimentologie et géochimie de formation du Miocène inférieur des Bétides et des Maghrébides. Implications paléogéographiques. Thèse d'Etat, Université Paris-Sud, Orsay, 388 p.

Rivière, M.; Bellon, H.; and Bonnot-Courtois, C. 1981. Aspectes géochemiques et géochronologiques du volcanisme pyroclastique foré dans le Golfe de Valence: Site 123 DSDP, leg 13 (Espagne)—conséquences géodynamiques. Mar. Geol. 41:295-307.

Rivière, M.; Boullin, J. P.; Courtois, C.; Gelard, J. P.; and Raoult, J. F. 1977. Etude minéralogique et géochimique des tuffites découvertes dans 1'Oligo-Miocène Kabyle (Grande Kabylie-Algérie). Comparaison avec les tuffites de la région de Malaga (Espagne). Bull. Soc. Geol. Fr., ser. 7, 19(5):1171-1177. 
Rivière, M., and Courtois, C. 1975. Étude minéralogique et géochimique des tuffites burdigaliennes de la région de Malaga (Espagne): intérêt des diagrammes de répartition des terres rares. C. R. Acad. Sci. Paris 280:1645-1648.

Rossi, P.; Guennoc, P.; Réhault, J. P.; Arnaud, N.; Jakni, B.; Poupeau, G.; Tegey, M.; et al. 1998. Importance du volcanisme calco-alcalin miocène sur la marge SO de la Corse (campagne Marco). C. R. Acad. Sci. Paris 327:369-376.

Ruffini, R.; Cadoppi, P.; d'Atri, A.; and Novaretti, A. 1995. Ash layers in the Monferrato (NW Italy): records of two types of magmatic source in Oligocene-Miocene time. Eclogae Geol. Helv. 88:347-363.

Russo, B., and Senatore, M. R. 1989. Ricerche sull'unità dauna: biostratigrafia e sedimentologia della successione di Monte Sidone nell'Appennino Dauno (Italia meridionale). Atti Accad. Peloritana Pericolanti, Classe Sci. Fis. Nat. 67(suppl. 1):79-97.

Ryan, W. B. F.; Hsü, K. J.; Honnorez, J.; Weibel, M.; Cann, J. R.; Ferrara, G.; Bigazzi, G.; Bonadonna, F. P.; and Giuliani, O. 1972. Petrology and geochemistry of the Valencia Trough volcanic rocks. Init. Rep. Deep Sea Drilling Proj. 13:767-773.

Santo, A., and Senatore, M. R. 1992. La successione stratigrafica dell'unità dauna a Monte Sidone (Castelluccio, Valmaggiore, Foggia). Mem. Soc. Geol. Ital. 41:431-438.

Savelli, C. 2015. Fast episodes of West-MediterraneanTyrrhenian oceanic opening and revisited relations with tectonic setting. Sci. Rep. 5:14271. https://doi.org/10.1038 /srep14271

Savelli, C.; Beccaluva, L.; Deriu, M.; Macciotta, G.; and Maccioni, L. 1979. K/Ar geochronology and evolution of the Tertiary "calcalkalic" volcanism of Sardinia (Italy). J. Volcanol. Geoth. Res. 5:257-269.

Schettino, A., and Turco, E. 2006. Plate kinematics of the western Mediterranean region during the Oligocene and early Miocene. Geophys. I. Int. 166:1398-1423.

2011. Tectonic history of the western Tethys since the Late Triassic. Geol. Soc. Am. Bull. 123:89-105.

Schmid, R. 1981. Descriptive nomenclature and classifications of pyroclastic rocks and fragments: recommendations of the IUGS Subcommission on the Systematics of Igneous Rocks. Geology 9:41-43.

Scotney, P.; Burgess, R.; and Rutter, E. H. 2000. ${ }^{40} \mathrm{Ar} /$ ${ }^{39} \mathrm{Ar}$ age of the Cabo de Gata volcanic series and si- placements on the Carboneras fault zone, SE Spain. I. Geol. Soc. Lond. 157:1003-1008.

Soria, J. M. 1998. La Cuenca de Antepaís norbética en la Cordillera Bética central (sector del Mencal): evolucion tectosedimentaria e historia de la subsidencia. Rev. Soc. Geol. Esp. 11(1-2):23-31.

. 1994. Sedimentación y tectónica durante el Mioceno en la región Sierra Arana-Mencal y su relación con la evolución geodinámica de la Cordillera Bética. Rev. Soc. Geol. Esp. 7:199-213.

Soria, J. M.; Estevez, A.; and Rodriguez-Perez, M. 1993. Materiales afines al Complejo del Campo de Gibraltar en el sector oeste del Mencal (Subbético medio, tercio central de la Cordillera Bética). Rev. Soc. Geol. Esp. 6(3-4):106-112.

Soria J. M.; Estévez, A.; and Serrano, F. 1992. Silexites et roches volcanoclastiques burdigaliennes de la zone subbétique centrale (région du Río Fardes-Mencal, Espagne méridionale). Signification géodynamique. C. R. Acad. Sci. Paris 314:1219-1226.

Tateo, F. 1993. Intercalazioni vulcano-sedimentarie nella Formazione di Antognola: le sezioni "Rio Nespolo" e "M. Varano" (Oligocene superiore, Appennino parmense). Mineral. Petrogr. Acta 36:61-79.

van Hinsbergen, D. J. J.; Vissers, R. L. M.; and Spakman, W. 2015. Origin and consequences of western Mediterranean subduction, rollback, and slab segmentation. Tectonics 33 393-419. https://doi.org/10.1002 /2013TC003349.

Wildi, W. 1983. La chaîne tello-rifaine (Algérie-MarocTunisie): structure, stratigraphie et évolution du Trias au Miocène. Rev. Geol. Dyn. Geogr. Phys. 24: 201-297.

Zaghloul, M. N.; Di Staso, A.; De Capoa, P.; and Perrone, V. 2007. Occurrence of upper Burdigalian silexite beds within the Beni Ider Flysch Fm. in the Ksar-es-Seghir area (Maghrebian Flysch Basin, Northern Rif, Morocco): stratigraphic correlations and geodynamic implications. Boll. Soc. Geol. Ital. 126:223-239.

Zaghloul, M. N.; Guerrera, F.; Loiacono, F.; Maiorano, P.; and Puglisi, D. 2002. Stratigraphy and petrography of the Beni Ider Flysch in the Tétouan area (Rif Chain, Morocco). Boll. Soc. Geol. Ital. 121:69-85. 